\title{
Color change of composites on substrates treated with $0.2 \%$ chlorhexidine
}

\author{
Alteração de cor de compósitos em substratos \\ tratados com clorexidina 0,2\%
}

\author{
Cristian SBARDELOTTO1 (iD https://orcid.org/0000-0001-6359-3294 \\ Fernanda de Carvalho Panzeri PIRES-DE-SOUZA1 iD https://orcid.org/0000-0002-1455-1538 \\ Rafaella Tonani TORRIERI ${ }^{1}$ iD https://orcid.org/0000-0002-2891-0343 \\ Carolina Noronha Ferraz de ARRUDA ${ }^{1}$ iD https://orcid.org/0000-0003-0850-461X
}

\section{ABSTRACT}

Objective: To evaluate the effect of $0.2 \%$ chlorhexidine digluconate $(\mathrm{CHX})$ as a pretreatment of two types of adhesive systems on color stability of composite resin restorations. Methods: Forty bovine teeth were prepared $(6 \times 6 \times 2 \mathrm{~mm})$ and randomly divided into 4 groups $(n=10)$ : SB - total etch adhesive (Single Bond 2, 3M ESPE); SB + CHX - dentin pretreatment with CHX (30 seconds) followed by SB application; Adh - self-etch adhesive (AdheSE, Ivoclar Vivadent); Adh + CHX - pretreatment with CHX (30 seconds) + followed by Adh application. The teeth were restored with Filtek Z350XT (3M ESPE) and photoactivated for 40 seconds. Color measurements (EasyShade, VITA) were performed following the CIE Lab scale at baseline, 1 and 3 months (distilled water $/ 37^{\circ} \mathrm{C}$ ). The mean color change values $(\Delta E)$ and coordinates $\left(L^{*}, a^{*}\right.$ and $\left.b^{*}\right)$ were statistically analyzed (2-way ANOVA, repeated measures, Bonferroni, $\left.p<.05\right)$. Results: Results showed that there was a reddening and yellowing of the restorative material after 3 months, differing ( $p<.05)$ from 1 month. There was no difference $(p>.05)$ regarding the treatment with $\mathrm{CHX}$. Conclusion: The $0.2 \% \mathrm{CHX}$ adhesive pretreatment did not produce greater color changes in composite resin restorations irrespective of the type of adhesive system used. However, time had significant effect on the change, regardless of the substrate treatment.

Indexing terms: Chlorhexidine. Composite resins. Color.

\section{RESUMO}

Objetivo: Avaliar o efeito de 0,2\% de digluconato de clorexidina (CHX) no pré-tratamento de dois tipos de sistemas adesivos na estabilidade de cor de restaurações de resina composta. Métodos: Quarenta dentes bovinos foram preparados (6x6x2mm) e foram divididos aleatoriamente em 4 grupos $(n=10)$ : SB - adesivo total etch (Single Bond 2, 3M ESPE); SB + CHX - pré-tratamento da dentina com CHX (30 segundos) seguido pela aplicação de SB; Adh - adesivo auto condicionante (AdheSE, Ivoclar Vivadent); Adh + CHX - pré-tratamento da dentina com CHX (30 segundos) seguido pela aplicação de Adh. Os dentes foram restaurados com Filtek Z350XT (3M ESPE) e fotoativados por 40 segundos. As leituras de cor (EasyShade, VITA) foram realizadas seguindo a escala CIE Lab em baseline, 1 e 3 meses (água destilada $/ 37^{\circ} \mathrm{C}$ ). A variação de $\operatorname{cor}(\Delta E)$ e as coordenadas ( $L^{*}, a^{*}$ e $b^{*}$ ) foram analisadas estatisticamente (2-way

$\boldsymbol{\nabla} \nabla \boldsymbol{\nabla}$

1 Universidade de São Paulo, Faculdade de Odontologia, Departamento de Materiais Dentários e Prótese. Av. do Café, s/n., 14040-904, Monte Alegre, Ribeirão Preto, SP, Brasil. Correspondence to: CNF ARRUDA. E-mail: <carolina.arruda@usp.br>.

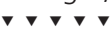

How to cite this article

Sbardelotto C, Pire-de-Souza FCP, Torrieri RT, Arruda CNF. Color change of composites on substrates treated with $0.2 \%$ chlorhexidine. RGO, Rev Gaúch Odontol. 2021;69:e2021004. http://dx.doi.org/10.1590/1981-86372021000420190083 
ANOVA, medidas repetidas, Bonferroni, $p<, 05)$. Resultados: Os resultados mostraram que houve avermelhamento e amarelamento na restauração após 3 meses, sendo diferente $(p<, 05)$ de 1 mês. Não houve diferença $(p>05)$ levando em consideração o tratamento com CHX. Conclusão: O pré-tratamento adesivo com 0,2\% CHX não produziu maiores alterações de cor nas restaurações em resina composta, independentemente do tipo de sistema adesivo utilizado. No entanto, o tempo teve efeito significativo sobre a alteração, independentemente do tratamento do substrato.

Termos de indexação: Clorexidina. Resinas compostas. Cor.

\section{INTRODUCTION}

Aesthetic dentistry has advanced rapidly with the development of new restorative materials. The formation of a hybrid layer composed of collagen fibrils is known to be primordial to provide adhesion [1] and degradation of these fibrils can directly affect the durability and longevity of the bonding process [1]. Nevertheless, the literature reports the occurrence of aesthetic restoration failures; biodegradation of the interface between the restorative composite and the tooth is considered a critical factor for the secondary loss of adhesion and microleakage [2].

Studies have shown that this fact occurs through the activation of enzymes present in the dental matrix, such as the matrixes of metalloproteinase (MMPs) $[3,4]$. The demineralized dentin contains MMPs 2, 3, 8, 9 and 20 and cathepsins in active forms. The carious process or the adhesive protocol makes the site acidic due to the use of prior acid etching with $37 \%$ phosphoric acid (total-etch adhesive systems) or acid $\mathrm{pH}$ primer (self-etch bonding systems). The MMPs exposed to the acid environment are activated and can degrade the collagen fibrils of the hybrid layer slowly, resulting in failure of the adhesiveness of composite restorations $[4,5]$ to the order of $36 \%$ and $70 \%$ in a period of time ranging between 12 and 14 months $[6,7]$.

To avoid failures and preserve the integrity of the bond interface, chlorhexidine (CHX) has been used as a non-specific inhibitor of MMPs and cysteine cathepsins [8]. Zhou et al. [9] showed that treating dentin powder for 20 seconds with SE Bond primers (Clearfil SE Bond) containing chlorhexidine $(0.5 \%, 1.0 \%$ and $2.0 \%)$ reduced the collagenolytic activities by $15.6 \%, 44.9 \%$, and $56.7 \%$ respectively. When treated for 2 minutes, SE Bond primer containing $2.0 \%$ chlorhexidine inhibited the collagenolytic activity by $41.1 \%$. Besides chlorhexidine effect on MMPs, the literature shows few reports regarding the color stability of restorations after the use of $\mathrm{CHX}[10,11]$.

The $\mathrm{CHX}$ is a cationic detergent of the bis-guanide class. The formulation most frequently used in dentistry is CHX digluconate, which has bactericidal, bacteriostatic and fungicidal properties with a broad spectrum of activity [12-16]. CHX acts on the cytoplasmic membrane of microorganisms, leading to a loss of osmotic control and consequent intracellular material breakdown. It binds to the hydroxyapatite of teeth, changing the electrical charge to compete with microorganisms [17].

The color stability of aesthetic restorations made with composite resins can be influenced by extrinsic factors such as intensity and duration of polymerization, exposure to environmental factors such as heat, water or food coloring [18].

Composite resin restorations may reflect the color of dental substrate due to their translucency, depending on the depth of the cavity to be restored, leading to change in the color of the final restoration [19]. In addition, the popularity of bleaching treatments has resulted in lighter tooth colors, requiring restorations with even more translucent materials [20].

Iskander et al. [15], evaluated the effect of two MMP-inhibitors (chlorhexidine and doxycycline), on the color stability of two shades of nanofilled resin composite and concluded that the accelerated aging caused color changed in a nanofilled resin composite regardless of MMP inhibitor used and the lighter shades showed less color stability when compared with darker shades.

In addition, $\mathrm{CHX}$ may promote protein denaturation which may result in dental staining due to the formation of ferric and stannous sulphite, leading to the formation of brownish substances called melanoidins [21]. Thus, used on dentin to prevent degradation of the hybrid layer, these could lead to change in the substrate color, which would result in alteration of the final color of the restoration.

The aim of this study was to evaluate the effect of pretreatment with $0.2 \% \mathrm{CHX}$ as a prior treatment to the adhesive protocol with different types of adhesive systems on the color stability of composite resin restorations. The null hypothesis tested was that there would be no significant color change after the use of $\mathrm{CHX}$ as a pretreatment of 
dentin in the adhesive protocol, irrespective of the type of adhesive system used.

\section{METHODS}

Forty bovine incisor teeth were selected after disinfecting with $0.5 \%$ thymol. Teeth were sectioned at the cemento-enamel junction (SYJ-150 Digital Display Low Speed Diamond Saw Complete Accessories, MTI Corporation, Richmond - CA, USA). The lingual surface of the teeth was included in PVC rings $(6 \times 2 \mathrm{~mm})$ with colorless chemically activated acrylic resins (Jet Classico LTDA, Campo Limpo Paulista - SP, Brazil) in order to leave the buccal portion parallel to the horizontal plane, in which cavity preparation $(6 \times 6 \times 2 \mathrm{~mm})$ was performed with the aid diamond drill 1343 (KG Sorensen, Cotia - SP, Brazil).

After preparation, the teeth were numbered and randomized by drawing to separate them into 4 groups according to the bond protocol used (Table 1). Both adhesive systems tested were applied in active mode and dried for 20 seconds before photoactivation. All photoactivation in the study were performed following manufacture's instruction.

The restorations were performed with composite resin Filtek Z350XT (3MEspe, Sumaré, SP, Brazil), shade A3D with $2 \mathrm{~mm}$ increments and photoactivation for 40 seconds (Flash Lite 1401 - Discus Dental, Culver City, CA, USA, > $\left.1.100 \mathrm{~mW} / \mathrm{cm}^{3}\right)$. The teeth were then stored in containers with distilled water in an oven at $37^{\circ} \mathrm{C}$ for 24 hours, after which initial color readouts (EasyShade, VITA Zahnfabrik, Bad Säckingen/Germany) were made. This equipment has a digital tip with a diameter of $6 \mathrm{~mm}$, and when activated, 19 optical fibers illuminate the object, which reflects the light that is captured by 2 spectrophotometric sensors that identify the color numerically. The optical color measurement geometry is circular with the specular component excluded, in which color evaluation is simulated by the $45 / 0$ geometry. The standard illuminant is D65 and the default observer is $2^{\circ}$. The excluded specular component is related to the color measurement on the surface of the sample, to avoid interference from surface brightness.

The pattern observation device is simulated by the following CIE L* $a * b *$ coordinates, recommended by CIE (Commission Internationale de L'Éclairage), and they are defined by a combination of Cartesian coordinates where a point is associated with a single color. This system consists of the $L^{*}$ axis - coordinate of lightness whose values range from 0 (black) to 100 (white). The other two axes, a* (tred; - green) and $b^{*}$ (+ yellow; - blue), at right angles to one another represent the saturation level and color dimension (CIE 15.2: 1986).

The color readouts were performed with the restored teeth placed on a white standard background (White Standard Sphere for $45^{\circ}, 0^{\circ}$ Reflectance and Color Gardner Laboratory Inc. Bethesda, Geretsried, Germany). The spectrophotometer was calibrated before to perform the three-color readouts for each sample; the means of these values were considered the initial values (TO) of the coordinates.

Table 1. Materials and bond protocols used.

\begin{tabular}{|c|c|c|c|c|}
\hline Adhesive System & Composition & Manufacturer & Group & Restorative procedure \\
\hline \multirow{2}{*}{$\begin{array}{l}\text { Adper Single Bond } 2 \\
\text { (total-etch) }\end{array}$} & \multirow{2}{*}{$\begin{array}{l}\text { BisGMA, HEMA, dimethacrylates, ethanol, } \\
\text { water, polyacrylic and polyalkanoic acid } \\
\text { methacrylate copolymer photo initiator }\end{array}$} & \multirow{2}{*}{$\begin{array}{l}\text { (3MEspe, Sumaré-SP, } \\
\text { Brazil) }\end{array}$} & SB & $\begin{array}{l}\text { Acid Conditioning (15s) + Washing } \\
\text { (30s) + Adhesive System (2 layers) + } \\
\text { Photoactivation (20s) }\end{array}$ \\
\hline & & & $\mathrm{SB}+\mathrm{CHX}$ & $\begin{array}{l}\text { Acid Conditioning (15s) + Washing } \\
\text { (30s) + CHX (30s) + Adhesive System } \\
\text { (2 layers) + Photoactivation (20s) }\end{array}$ \\
\hline \multirow{2}{*}{ AdheSE (self-etch) } & \multirow{2}{*}{$\begin{array}{l}\text { AdheSE Primer: dimethacrylate, phosphonic } \\
\text { acid acrylate, initiators and stabilizers in } \\
\text { aqueous solution. } \\
\text { AdheSE Bond: HEMA, dimethacrylate, silicon } \\
\text { dioxide, initiators and stabilizers }\end{array}$} & \multirow{2}{*}{$\begin{array}{l}\text { (Ivoclar Vivadent, } \\
\text { Schaan, Liechtenstein) }\end{array}$} & Adh & $\begin{array}{l}\text { Primer }(15 s)+\text { Bond + Photoactivation } \\
\text { (10s) }\end{array}$ \\
\hline & & & $\mathrm{Adh}+\mathrm{CHX}$ & $\begin{array}{l}\text { Primer (15s) + CHX (30s) + Bond + } \\
\text { Photoactivation (10s) }\end{array}$ \\
\hline
\end{tabular}

Note: Acid conditioning: Phosphoric acid 37\% (Villevie - Joinville - SC, Brazil); CHX: Irrigation with 0.2\% Chlorhexidine solution (Daterra - Pharmacy of manipulation, Ribeirao Preto, SP, Brazil); Photoactivation (Flash Lite 1401 - Discus Dental, Culver City, CA, USA, > 1.100mW/cm³). 
After 30 (T30) and 90 (T90) days stored in distilled water in an incubator at $37^{\circ} \mathrm{C}$, new color readouts were performed, according to the previously described methodology. The color stability of the teeth was calculated from the following formula.

$$
\begin{gathered}
\Delta E=\left[\left(\Delta L^{*}\right)^{2}+\left(\Delta a^{*}\right)^{2}+\left(\Delta b^{*}\right)^{2}\right]^{1 / 2} \\
\text { When: } \\
\Delta L^{*}=L^{*}{ }_{f}-L^{*}{ }_{i} \\
\Delta a^{*}=a^{*}{ }_{f}-a^{*}{ }_{i} \\
\Delta b^{*}=b^{*}{ }_{f}-b^{*}{ }_{i}
\end{gathered}
$$

Since $L * i, a * i$ and $b * i$ were referred to as the initial measure of color, and $L^{*}{ }_{f^{\prime}} a^{*}{ }_{f}$ and $b^{*}{ }_{f^{\prime}}$ color measure after the analysis times tested. For analysis of color stability at different experimental time intervals, the values were always compared with baseline values. The values of $\Delta \mathrm{E}$, $L^{*}, a^{*}$ and $b^{*}$ adhered to normal distribution as verified by the Shapiro-Wilk test and were analyzed statistically (2-way ANOVA, repeated measures, Bonferroni, $p<.05$ ).

\section{RESULTS}

Table 2 shows the baseline, 1 and 3 months mean values and standard deviations for $L^{*}, a^{*}$ and $b^{*}$ (2-way
ANOVA, repeated measures, Bonferroni test, $p<.05)$. Regarding the $L^{*}$ coordinate, time was not significant to treatment. The highest changes in $L^{*}$ values occurred when the substrate was treated with $\mathrm{SB}$, which were similar $(p>05)$ to Adh $+\mathrm{CHX}$, after 1 month. After 90 days, SB values were still lower than Adh.

The results showed that there was a decrease in $L^{*}$ coordinate for the majority of the groups, indicating "darkening" of the samples after aging, except for SB + $\mathrm{CHX}$ and Adh (without $\mathrm{CHX}$ ) after 1 month of treatment. Thus, the treatment with $\mathrm{CHX}$ was found to be a significant factor for the change in this coordinate when the etchand-rinse adhesive system was used.

Regarding coordinates $a^{*}$ and $b^{*}$, the treatments were not significant. However, there was a reddening of the samples due to time, when treated with $\mathrm{SB}$, after 1 and 3 months, Adh $+\mathrm{CHX}$ after 1 month and when treated with Adh and $\mathrm{SB}+\mathrm{CHX}$ after 3 months. There was a yellowing of the samples after 3 months for all groups.

\begin{tabular}{|c|c|c|c|c|c|c|c|c|c|c|c|c|}
\hline \multirow{4}{*}{ Baseline } & \multicolumn{12}{|c|}{ Adhesives } \\
\hline & \multicolumn{6}{|c|}{ Total-etch } & \multicolumn{6}{|c|}{ Self-etch } \\
\hline & \multicolumn{3}{|c|}{ SB } & \multicolumn{3}{|c|}{$\mathrm{SB}+\mathrm{CHX}$} & \multicolumn{3}{|c|}{ Adh } & \multicolumn{3}{|c|}{$\mathrm{Adh}+\mathrm{CHX}$} \\
\hline & 70,89 & 6,97 & 44,91 & 71,26 & 6,94 & 45,6 & 72,84 & 6,89 & 45,94 & 71,39 & 6,87 & 45,25 \\
\hline 1 month & \multicolumn{3}{|c|}{$2,93(1,55) \mathrm{A}$} & \multicolumn{3}{|c|}{$2,09(0,92) \mathrm{A}$} & \multicolumn{3}{|c|}{$1,95(1,46) \mathrm{A}$} & \multicolumn{3}{|c|}{$1,96(1,18) B$} \\
\hline
\end{tabular}
Regarding $\Delta \mathrm{E}$ (figure 1), there was a color change after 1 and 3 months for all groups, with no statistical difference between them.

Table 2. Comparison of $\triangle E$ means (2-way ANOVA, repeated measures, Bonferroni, $p<.05$ )

Note: Different letters in the column indicate statistically significant difference. For all comparisons on the line $p<.05$

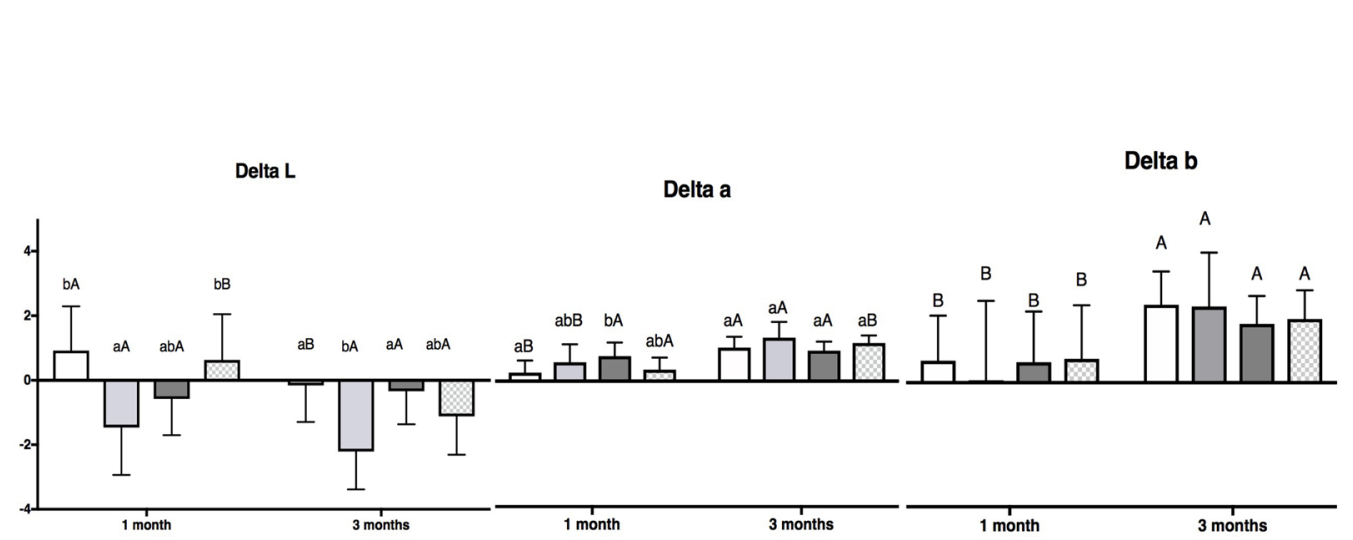

Figure 1. $\Delta E$ means after 1 and 3 months. 


\section{DISCUSSION}

The aim of this study was to evaluate the effect of pretreatment with $0.2 \% \mathrm{CHX}$, using two adhesive systems, on the color stability of composite resin restorations. After the data analysis, the null hypothesis was accepted, and there was no significant difference in the color change of the restorative material after pretreatment of the dentin with $\mathrm{CHX}$, irrespective of the adhesive protocol used.

The CHX solution inhibits the action of MMPs on the adhesive interface [22] retards degradation and increases longevity of the hybrid layer [23].

In addition, it has antimicrobial action, [12-16] and is used as disinfectant solution in cavity preparations. The CHX solution is known to stain teeth, restorations, prostheses and the tongue after prolonged use $[12,24]$.

The mechanism of chlorhexidine staining has not yet been fully established, but one of the hypotheses is its catalytic participation in non-enzymatic reactions of browning (Maillard's Reactions). Glycoproteins participate as substrates for these reactions of condensation and polymerization, resulting in the formation of dark substances called melanoidins; and this denaturation of proteins is related to dental staining by formation of ferric and stannous sulphide [21].

The stability of the hybrid layer composed of demineralized collagen and polymerized resinous monomers contributes to the color stability of restorations [15]. The resin matrix is composed of transparent monomers, that are translucent, because their structure is composed of a resinous base filled with small particles and other additives [25].

However, it is necessary to consider, that the measure of $\Delta \mathrm{E}$ between two color stimuli, represented by the combination of 3 coordinates, is a measure of Euclidean distance between two points represented in space, used to roughly represent the magnitude of the color difference between the objects of the same size and shape, seen in identical environments, by an observer adapted to the chromaticity field close to the mean of daylight [26] a spatial measure of the color difference, without however having a description of which coordinate was responsible for the color change. Thus, it is always important to evaluate the coordinates separately to better understand the change that has occurred.

In the present study, nanoparticle composite resin was used, with filler particles of 0.6 - 20 nanometers, on an average. Due to their reduced size, the filler particles are presented in the form of agglomerates, which improves the polishing of the restorations and allows a better dispersion of light inside, leading to better aesthetic properties, especially translucency, in comparison with the other types of resin composites [26]. The higher the translucency of a restoration, the greater the amount of light reflected [20]. If the treated substrate has a stained surface or darker the color than that of the dentin itself, the degree of light reflection can be changed [20] and result in color change of a restorative material [15].

According to a study by Souza et al. [10], the chlorhexidine solution applied on enamel and dentin does not cause color change. Dutra-Correa et al. [11], also evaluated the use of $2 \%$ chlorhexidine prior to the adhesive system, which was not able to change the color of the restoration after 6 and 18 months. The present study corroborates these results.

The color changes that occurred in the present study were time-dependent for $a^{*}$ and $b^{*}$ coordinates, that is, they showed higher values after 3 months of aging, irrespective of the type of adhesive system used. The Adh adhesives have acidic monomers in their composition, which produce lower surface demineralization of the dentin layer of the substrate to form the hybrid layer [27]. Deficient infiltration of monomers into this layer can create nanoscale in the hybrid layer resulting in water infiltration and degradation of monomers over time, a factor that may justify the higher color change values found after 3 months. These results corroborate a study by Iskander et al. [15].

Moreover, self-etch adhesives are composed of phosphate monomers, which bind to free radicals released due to $\mathrm{CHX}$ degradation, leading to the formation of ferric and stannous sulfide, which may be responsible for these changes in color and brightness [21].

The results for the coordinates indicated that there was greater saturation of the yellow and red hues, represented by the higher values of the coordinates $a^{*}$ and $b^{*}$, regarding time.

The highest values for the $L^{*}$ coordinate occurred for Groups Adh and SB + CHX after 1 month of aging, with results differing $(p<.05)$ from those of $A d h+C H X$ and SB. In addition, the $a^{*}$ coordinate presented higher values for substrates treated with SB and Adh after 3-month.

Substrate treatments were not significant for the change in the $b^{*}$ coordinate after 1 and 3 months, 
irrespective of the type of adhesive system or treatment used. However, the time was significant $(p<.05)$, indicating saturation of the yellow hue after 3 months of aging for all groups. These results contradicted those of a study that reported that CHX was considered a stable solution [28].

This study had limitations, such as being an in vitro study. In addition, the number of dentin adhesives used, and the time intervals of analysis studied (3 months) should be higher. The universal adhesive systems, which can be used in the total-etch and self-etch mode and have different compositions to those of the adhesives used, in addition to longer aging times, could be investigated.

\section{CONCLUSIONS}

Despite the limitations of the study, it was possible to conclude that the $0.2 \% \mathrm{CHX}$ adhesive pretreatment did not produce greater color changes in composite resin restorations irrespective of the type of adhesive system used. However, time had significant effect on the change, regardless of the substrate treatment.

\section{Collaborators}

C SBARDELOTTO, acquisition of data, analysis and interpretation of data, drafting of manuscript. FCP PIRES-DESOUZA, study conception and design, analysis and interpretation of data, critical revision. RT TORRIERI, acquisition of data, CNF ARRUDA, analysis and interpretation of data, drafting of manuscript, critical revision.

\section{REFERENCES}

1. Breschi L, Martin P, Mazzoni A, Nato F, Carrilho M, Tjäderhane $\mathrm{L}$, et al. Use of a specific MMP-inhibitor (galardin) for preservation of hybrid layer. Dent Mater. 2010;26(6):571-8. http://dx.doi.org/10.1016/j.dental.2010.02.007

2. Donmez N, Belli S, Pashley DH, Tay FR. Ultrastructural correlates of in vivo/in vitro bond degradation in self-etch adhesives. J Dent Res. 2005;84(4):355-9. http://dx.doi. org/10.1177/154405910508400412

3. Carvalho RM, Manso AP, Geraldeli S, Tay FR, Pashley $\mathrm{DH}$. Durability of bonds and clinical success of adhesive restorations. Dent Mater. 2012;28(1):72-86. http://dx.doi. org/10.1016/j.dental.2011.09.011

4. Mazzoni A, Tjäderhane L, Checchi $V$, Di Lenarda R, Salo T, Tay FR, et al. Role of dentin MMPs in caries progression and bond stability. J Dent Res. 2015;94(2):241-51. http://dx.doi. org/10.1177/0022034514562833
5. Lührs AK, De Munck J, Geurtsen W, Van Meerbeek B. Does inhibition of proteolytic activity improve adhesive luting? Eur J Oral Sci. 2013;121(2):121-31. http://dx.doi.org/10.1111/ eos. 12018

6. Carrilho MR, Geraldeli S, Tay F, de Goes MF, Carvalho RM, Tjaderhane $L$, et al. In vivo preservation of the hybrid layer by chlorhexidine. J Dent Res. 2007;86(6):529-33. http://dx.doi. org/10.1177/154405910708600608

7. Ricci HA, Sanabe ME, de Souza CCA, Pashley DH, Hebling J. Chlorhexidine increases the longevity of in vivo resin-dentin bonds. Eur J Oral Sci. 2010;118(4):411-6.

8. Scaffa PM, Vidal CM, Barros N, Gesteira TF, Carmona AK, Breschi $L$, et al. Chlorhexidine inhibits the activity of dental cysteine cathepsins. J Dent Res. 2012;91(4):420-5.

9. Zhou J, Tan J, Yang X, Xu X, Li D, Chen L. MMP-inhibitory effect of chlorhexidine applied in a self-etching adhesive. J Adhes Dent. 2011;13(2):111-5.

10. Souza M, Cecchin D, Barbizam J V, Almeida JF, Zaia AA, Gomes BP, et al. Evaluation of the colour change in enamel and dentine promoted by the interaction between $2 \%$ chlorhexidine and auxiliary chemical solutions. Aust Endod J. 2013;39(3):107-11.

11. Dutra-Correa M, Saraceni CH, Ciaramicoli MT, Kiyan VH, Queiroz CS. Effect of chlorhexidine on the 18-month clinical performance of two adhesives. J Adhes Dent. 2013;15(3):287-92.

12. Addy M, Prayitno S, Taylor L, Cadogan S. An in vitro study of the role of dietary factors in the aetiology of tooth staining associated with the use of chlorhexidine. J Periodontal Res. 1979;14(5):403-10.

13. Cadenaro M, Pashley DH, Marchesi G, Carrilho M, Antoniolli F, Mazzoni A, et al. Influence of chlorhexidine on the degree of conversion and E-modulus of experimental adhesive blends. Dent Mater. 2009;25(10):1269-74.

14. Breschi L, Mazzoni A, Nato F, Carrilho M, Visintini E, Tjaderhane $L$, et al. Chlorhexidine stabilizes the adhesive interface: a 2-year in vitro study. Dent Mater. 2010;26(4):320-5.

15. Iskander M, Elkassas D, Mohsen MA. Effect of two matrix metalloproteinase inhibitors on the color stability of a nanofilled resin composite. Oper Dent. 2015;40(1):E11-20.

16. Khosravi M, Esmaeili B, Nikzad F, Khafri S. Color Stability of Nanofilled and Microhybrid Resin-Based Composites Following Exposure to Chlorhexidine Mouthrinses: An In Vitro Study. J Dent. 2016;13(2):116-25.

17. Rabe P, Twetman S, Kinnby B, Svensater G, Davies JR. Effect of fluoride and chlorhexidine digluconate mouthrinses on plaque biofilms. Open Dent J. 2015;9:106-11.

18. Bagheri R, Burrow MF, Tyas M. Influence of food-simulating solutions and surface finish on susceptibility to staining of aesthetic restorative materials. J Dent. 2005;33(5):389-98.

19. Lee YK, Lim BS, Kim CW. Difference in the colour and colour change of dental resin composites by the background. J Oral Rehabil. 2005;32(3):227-33.

20. Cruvinel DR, Garcia Lda F, Consani S, de Carvalho Panzeri Pires-de-Souza F. Composites associated with pulp-protection 
material: color-stability analysis after accelerated artificial aging. Eur J Dent. 2010;4(1):6-11.

21. Eriksen $H M$, Nordbo $H$, Kantanen $H$, Ellingsen JE. Chemical plaque control and extrinsic tooth discoloration. A review of possible mechanisms. J Clin Periodontol. 1985;12(5):345-50.

22. Erhardt MC, Osorio R, Toledano M. Dentin treatment with MMPs inhibitors does not alter bond strengths to cariesaffected dentin. J Dent. 2008;36(12):1068-73.

23. Campos EA, Correr GM, Leonardi DP, Pizzatto E, Morais EC. Influence of chlorhexidine concentration on microtensile bond strength of contemporary adhesive systems. Braz Oral Res. 2009;23(3):340-5.

24. Lepri $C P$, Ribeiro $M V$, Dibb A, Palma-Dibb RG. Influence of mounthrinse solutions on the color stability and microhardness of a composite resin. Int J Esthet Dent. 2014;9(2):238-46.

25. Avsar A, Yuzbasioglu E, Sarac D. The Effect of Finishing and Polishing Techniques on the Surface Roughness and the Color of Nanocomposite Resin Restorative Materials. Adv Clin Exp Med. 2015;24(5):881-90.

26. Pecho OE, Ghinea R, Perez MM, Della Bona A. Influence of Gender on Visual Shade Matching in Dentistry. J Esthet Restor Dent [Internet]. 2017 Apr 1;29(2):E15-23. Available from: https://doi.org/10.1111/jerd.12292

27. Besse V, Derbanne MA, Pham TN, Cook WD, Le Pluart L. Photopolymerization study and adhesive properties of selfetch adhesives containing bis(acyl)phosphine oxide initiator Dent Mater. 2016;32(4):561-9.

28. Rasimick BJ, Wan J, Musikant BL, Deutsch AS. Stability of doxycycline and chlorhexidine absorbed on root canal dentin. J Endod. 2010;36(3):489-92.

Received on: 21/5/2019

Final version resubmitted on: 6/11/2019

Approved on: 27/12/2019 